\title{
Kelompok Dukungan Sebaya berhubungan dengan Kualitas Hidup Orang dengan HIV/AIDS
}

\author{
Sekar Ayuningtyas ${ }^{1}$, Sugih Wijayati ${ }^{1}$, Muhamad Jauhar $^{2 *}$ \\ ${ }^{1}$ Jurusan Keperawatan, Poltekkes Kemenkes Semarang, Semarang, Jawa Tengah, Indonesia \\ ${ }^{2}$ Fakultas Ilmu Kesehatan, Universitas Muhammadiyah Kudus, Jawa Tengah, Indonesia \\ *muhamadjauhar@umkudus.ac.id
}

\begin{abstract}
The phenomenon of HIV / AIDS has an impact on the national stablity. The factors is risky sexual behavior and drugs. The impact is a community stigma that affects the quality of life among people living with HIVIAIDS (PLWHA). Peer group support can improve the quality of life among PLWHA. This study aims to identify the relationship peer group support and the quality of life among PLWHA. This study used an analytic observation design with a cross sectional approach. The study used simple random sampling. A sample of 62 clients in the Peer Support Group (KDS) Arjuna Plus Semarang. The study used a peer group support questionnaire (validity value 0.335-0.708 and reliability 0.426) and quality of life (validity value 0.325-0.602 and reliability 0.582). Data analysis using Pearson product moment correlation test. The mean ageof PLWHA is 33.56 years, male (62.9\%), high school (40.3\%), private employees (75.8\%). Peer group support associated with quality of life among PLWHA ( $p$ value $=0.045)$. Nurses as a health service providers collaborate with Peer Support Groups in improving the quality of life among PLWHA.
\end{abstract}

Keyword : HIV/AIDS; peer support group; quality of life

\begin{abstract}
Abstrak
Fenomena peningkatan kasus HIV/AIDS berdampak pada stabilitas pembangunan nasional di suatu negara. Salah satu faktornya adalah perilaku seksual berisiko dan narkoba. Dampaknya adalah stigma masyarakat berpengaruh terhadap kualitas hidup Orang dengan HIV/AIDS (ODHA). Dukungan kelompok sebaya diperlukan untuk meningkatkan kualitas hidup ODHA. Penelitian ini bertujuan untuk mengidentifikasi hubungan dukungan kelompok sebaya dan kualitas hidup ODHA. Desain penelitian menggunakan observasi analitik berbasis cross sectional. Teknik sampling menggunakan simple random sampling. Sampel 62 klien di Kelompok Dukungan Sebaya (KDS) Arjuna Plus Semarang. Penelitian menggunakan kuesioner dukungan kelompok sebaya (nilai validitas 0,335-0,708 dan reliabilitas 0,426 ) dan kualitas hidup (nilai validitas 0,325-0,602 dan reliabilitas 0,582). Analisis data menggunakan uji korelasi product moment pearson. Karakteristik ODHA menunjukkan rerata usia 33,56 tahun, mayoritas jenis kelamin laki-laki (62,9\%), pendidikan terakhir SMA $(40,3 \%)$, bekerja sebagai pegawai swasta $(75,8 \%)$. Gambaran kelompok dukungan sebaya tinggi $(98,4 \%)$ dan kualitas hidup baik $(74,2 \%)$. Dukungan kelompok sebaya berhubungan dengan kualitas hidup secara bermakna pada ODHA di Kelompok Dukungan Sebaya (KDS) Arjuna Plus Semarang (nilai $\mathrm{p}=$ 0,045). Perawat sebagai pemberi layanan kesehatan HIV/AIDS berkolaborasi dengan Kelompok Dukungan Sebaya dalam meningkatkan kualitas hidup ODHA.
\end{abstract}

Kata kunci : HIV/AIDS; kelompok dukungan sebaya; kualitas hidup

Jurnal Keperawatan Raflesia, Volume 3 Nomor 1, Mei 2021

ISSN: (p) 2656-6222, (e) 2657-1595 DOI 10.33088/jkr.v3i1.623

Available online: https://jurnal.poltekkes-kemenkes-bengkulu.ac.id/index.php/jkr 


\section{PENDAHULUAN}

Fenomena peningkatan kasus HIV/AIDS berdampak pada masalah pembangunan nasional. HIV/AIDS di Indonesia dapat mengancam masyarakat karena dampak dari faktor resiko terutama perilaku seksual, penggunaan narkoba suntik yang semakin meningkat. Beberapa faktor risiko tidak hanya berkaitan dengan perilaku seksual dan penggunaan narkoba suntik tetapi juga adanya masalah sosial dan ekonomi. (Kemenkes RI, 2018).

Maharani (2017) menyatakan bahwa HIV/AIDS merupakan permasalahan yang menjadi isu bersama dan menarik perhatian berbagai komponen masyarakat di seluruh dunia, khususnya pada petugas kesehatan. HIV/AIDS merupakan penyakit disebabkan karena menurunnya sistem kekebalan tubuh. World Health Organization (Kemenkes RI, 2018) menjelaskan bahwa pada tahun 2016, ODHA di dunia mencapai 38 juta jiwa dan kemungkinan bisa bertambah. Diperkirakan yang meninggal karena HIV/AIDS mencapai 1 juta jiwa.

Berdasarkan data (Kemenkes RI, 2018), jumlah kasus HIV-AIDS di Indonesia sebanyak 57.580 kasus pada tahun 2017, mengalami peningkatan $0,12 \%$ dari tahun sebelumnya. Jumlah kasus HIV-AIDS di Provinsi Jawa Tengah menduduki peringkat ketiga sebanyak 2.480 kasus pada tahun 2015, mengalami peningkatan sebesar 0,11\% dari tahun 2014 (Dinkes Provinsi Jawa Tengah, 2015). Kota Semarang menjadi daerah tertinggi dengan kasus HIV-AIDS pada tahun 2018 mencapai 4.741 kasus, peningkatan sebesar 4,7\% dari tahun 2017 (Dinas Kesehatan Kota Semarang, 2018).

Berdasarkan studi pendahuluan, jumlah kasus HIV/AIDS di Kelompok Dukungan Sebaya (KDS) Arjuna Plus Semarang mencapai 100 orang diantaranya 10 orang anak-anak, 50 orang laki-laki (dewasa) dan 40 orang perempuan (dewasa). KDS Arjuna Plus Semarang merupakan salah satu kelompok dukungan yang paling aktif dengan jumlah ODHA terbanyak dibandingkan kelompok dukungan sebaya lain di wilayah Kota Semarang. Penyakit HIV/AIDS muncul karena berbagai macam factor penyebab. Faktor resiko heteroseksual serta homoseksual merupakan salah satu penyebab kasus HIV/AIDS meningkat.

Dalam kehidupan sehari-hari ODHA harus mampu menghadapi berbagai masalah kompleks. Permasalahan yang dihadapi tidak hanya pada aspek fisiologis akibat terinfeksi HIV/AIDS, namun juga masalah stigma dan diskriminasi sehingga terjadi peningkatan beban psikologis dan berdampak pada penurunan kualitas hidup. Kualitas hidup berhubungan dengan halhal kompleks seperti, kondisi psikologis, kesehatan fisik, kemandirian, interaksi sosial, dan sosialisasi individu dengan lingkungan sekitar. Dampak dari berbagai permasalahan tersebut berujung pada perbedaan dalam kehidupan sosial yang membuat ODHA tidak memiliki keinginan membuka status dan menghambat untuk 
berinteraksi dengan masyarakat sekitar (Diatmi \& Fridari, 2014).

Diatmi \& Fridari (2014) menjelaskan salah satu faktor yang berperan dalam peningkatan kualitas hidup pada ODHA adalah KDS. KDS memberikan kenyamanan, perhatian, penghargaan dan tidak ada diskriminasi, sehingga ODHA merasa dicintai, dihargai, dan menjadi bagian dari masyarakat. Menurut (Rozi, 2016) KDS sangat memfasilitasi dalam mengurangi risiko penularan penyakit HIV/AIDS. Berdasarkan hal tersebut dukungan sosial harus diberikan kepada ODHA sehingga dapat meningkatkan kualitas hidup ODHA.

KDS merupakan dukungan yang diberikan untuk orang menghadapi tantangan seperti infeksi, komunitas tertentu, dan orang yang mempunyai masalah yang sama seperti ODHA. Keberadaan KDS berhubungan dengan kualitas hidup ODHA. Kualitas hidup mempengaruhi kepercayaan diri, pemahaman, akses layanan kesehatan, perilaku pencegahan penularan penyakit, motivasi terhadap kepatuhan minum obat, serta merupakan kegiatan positif dibandingkan dengan ODHA yang tidak mendapatkan dukungan dari kelompok sebaya (Johan, Wahyuni \&Pitoyo, 2014).

Berdasarkan survei pendahuluan di KDS Arjuna Plus Semarang, manajer kasus menyatakan bahwa untuk proporsi kualitas hidup ODHA yang buruk tentang persepsi kualitas hidup mencapai $81 \%$. Sebanyak $58 \%$ ODHA menerima dukungan sosial kurang dan 59\% ODHA memiliki kualitas hidup rendah. Masalah-masalah tersebut mengakibatkan ODHA mengalami depresi, cemas, dan keinginan mengakhiri hidup. ODHA menyatakan bahwa dirinya sudah tidak berguna lagi dan tidak bermanfaat, sehingga dapat menurunkan motivasi dalam melakukan perawatan diri. Selain itu, ODHA menjadi malas beraktifitas, nafsu makan menurun, ketidakinginan untuk berolahraga. Berdasarkan hal tersebut, masalah-masalah yang berkaitan dengan HIV/AIDS dapat dicegah dengan meningkatkan dukungan terhadap ODHA. Dukungan dari sebaya mampu meningkatkan motivasi sehingga ODHA mampu menjalani perawatan dan pengobatan HIV/AIDS dengan maksimal. Selain itu, hal penting lainnya, dengan adanya motivasi yang kuat dari sebaya dapat meningkatkan kualitas hidup ODHA. Perawat dalam hal berperan sebagai pemberi perawatan, pendidik, konselor, kolaborator. Perawat memberikan perawatan secara langsung pada ODHA, memberikan pemahaman tentang manajemen penyakit, memberikan dukungan dan motivasi serta mengkoordinir tenaga kesehatan lain dalam memaksimalkan kualitas hidup ODHA. Tujuan penelitian yaitu mengidentifikasi hubungan antara kelompok dukungan sebaya dan kualitas hidup ODHA di KDS Arjuna Plus Semarang.

\section{METODE}

Desain penelitian menggunakan observasi analitik berbasis cross sectional. Variabel 
independen yaitu Kelompok Dukungan Sebaya yaitu sebuah komunitas dimana terdapat dukungan setiap anggota kelompok dalam kehidupan sehari-hari untuk menghadapi tantangan yang sama, diukur dengan menggunakan skala guttman dan ordinal, hasil ukur tinggi $\geq$ median dan rendah $<$ median. Variabel dependen yaitu Kualitas Hidup artinya derajat kepuasan hati setelah terpenuhinya kebutuhan eksternal dan persepsi mencakup kesehatan fisik, psikologis, sosial, dan kebebasan, diukur menggunakan skala guttman dan ordinal, hasil ukur baik $\geq$ median dan kurang baik $<$ median. Penelitian ini dilakukan di KDS Arjuna Plus Semarang pada bulan Januari sampai Maret tahun 2019. Populasi penelitian merupakan ODHA dengan usia lebih dari 20 tahun. Jumlah responden penelitian sebanyak 62 klien. Teknik sampling menggunakan simple random sampling. Kriteria inklusi yaitu terkonfrimasi HIV positif berdasarkan hasil laboratorium/dokter, usia lebih dari 20 tahun, bisa menulis, membaca, berkomunikasi dalam Bahasa Indonesia, dan menjalani terapi $\mathrm{ARV} \geq 1$ bulan.

Peneliti menggunakan kuesioner kelompok dukungan sebaya dan kualitas hidup ODHA yang dikembangkan oleh (Johan, Wahyuni \& Pitoyo, 2014). Peneliti melakukan uji validitas dan reliabilitas kuesioner pada 30 ODHA di LSM Plus Kota Semarang. Nilai validitas 0,3350,708 (kualitas hidup) dan 0,325-0,602 (kelompok dukungan sebaya). Nilai reliabilitas 0,582 (kualitas hidup) dan 0,426 (kelompok dukungan sebaya).
ODHA mengisi informed consent dan mendapatkan penjelasan tentang prosedur penelitian sebelum mengisi kuesioner. Analisis univariat dilakukan pada data demografi, kualitas hidup, dan kelompok dukungan sebaya. Data jenis kelamin, pendidikan, pekerjaan, kelompok dukungan sebaya, dan kualitas hidup dideskripsikan dalam frekuensi dan persentase. Data usia dideskripsikan dalam mean dan standar deviasi. Analisis bivariate menggunakan uji statistic korelasi pearson product moment untuk mengetahui kekuatan hubungan antara korelasi 2 variabel. Penelitian ini telah mendapatkan surat keterangan lolos uji etik dari Komite Etik Fakultas Kedokteran Universitas Islam Sultan Agung Semarang.

\section{HASIL}

\section{A. Karakteristik ODHA di KDS Arjuna Plus Semarang}

Tabel 1. Karakteristik ODHA di KDS Arjuna Plus Semarang berdasarkan usia $(n=62)$

\begin{tabular}{ccccc} 
Variabel & Mean & S.D & Min-Max & $95 \%$ CI \\
\hline Usia & 33,56 & 7,617 & $24-50$ & $31,63-35.50$ \\
\hline
\end{tabular}

\section{Tabel 1. Mendeskripsikan nilai rata-rata usia pada ODHA di KDS Arjuna Plus Semarang adalah 33,56 tahun $\pm 7,617$. Usia terendah ODHA adalah 24 tahun dan yang tertinggi usia ODHA adalah 50 tahun.}


Tabel 2. Karakteristik ODHA di KDS Arjuna Plus Semarang berdasarkan jenis kelamin, pendidikan, dan pekerjaan $(n=62)$

\begin{tabular}{lcc}
\hline \multicolumn{1}{c}{ Karakteristik } & $\begin{array}{c}\text { Frekuensi } \\
\text { (f) }\end{array}$ & $\begin{array}{c}\text { Persentase } \\
(\%)\end{array}$ \\
\hline Jenis Kelamin & & \\
Laki-laki & 39 & 62,9 \\
Perempuan & 23 & 37,1 \\
\hline Pendidikan & & \\
SD & 6 & 9,7 \\
SMP & 19 & 30,6 \\
SMA & 25 & 40,3 \\
Perguruan Tinggi & 12 & 19,4 \\
\hline Pekerjaan & & \\
Tidak Bekerja & 11 & 17,7 \\
Pegawai swasta & 47 & 75,8 \\
Pedagang & 3 & 4,8 \\
PNS & 1 & 1,6 \\
\hline Total & 62 & 100 \\
\hline
\end{tabular}

Tabel 2 mendeskripsikan ODHA di KDS Arjuna Plus Semarang sebagian besar berjenis kelamin laki-laki sebanyak 39 orang $(62,9 \%)$. Pendidikan terakhir ODHA adalah tingkat SMA sebanyak 25 orang (40,3\%), dan sebagian besar pekerjaan ODHA adalah pegawai swasta sebanyak 46 orang $(75,8 \%)$.

\section{B. Gambaran Kelompok Dukungan Sebaya dan Kualitas Hidup ODHA di KDS Arjuna Plus Semarang}

Tabel 3. Gambaran Kelompok Dukungan Sebaya dan Kualitas Hidup pada ODHA di KDS Arjuna Plus Semarang $(n=62)$

\begin{tabular}{lcc}
\hline \multicolumn{1}{c}{ Variabel } & $\begin{array}{c}\text { Frekuensi } \\
(\mathrm{f})\end{array}$ & $\begin{array}{c}\text { Persentase } \\
(\%)\end{array}$ \\
\hline Kelompok & & \\
$\begin{array}{l}\text { Dukungan Sebaya } \\
\text { Tinggi }\end{array}$ & 61 & 98,4 \\
Rendah & 1 & 1,6 \\
\hline Kualitas Hidup & & \\
Baik & 46 & 74,2 \\
Kurang Baik & 16 & 25,8 \\
\hline Total & 62 & 100 \\
\hline
\end{tabular}

Tabel 3 mendeskripsikan mayoritas ODHA di KDS Arjuna Plus Semarang memiliki kualitas hidup baik yaitu sebanyak 46 orang (74,2\%). Hampir seluruh ODHA di KDS Arjuna Plus Semarang mendapatkan dukungan dari KDS yaitu sebanyak 61 orang $(98,4 \%)$. 


\section{Kelompok Dukungan Sebaya (KDS) berhubungan dengan Kualitas Hidup ODHA di KDS Arjuna Plus Semarang.}

Tabel 4. Keeratan Hubungan Kelompok Dukungan Sebaya (KDS) dengan Kualitas Hidup pada ODHA di KDS Arjuna Plus Semarang $(n=62)$

\begin{tabular}{|c|c|c|c|c|c|c|c|c|}
\hline \multirow{3}{*}{$\begin{array}{c}\text { Kelompok } \\
\text { Dukungan } \\
\text { Sebaya } \\
\end{array}$} & \multicolumn{5}{|c|}{ Kualitas Hidup } & \multirow[t]{2}{*}{ Total } & \multirow[t]{2}{*}{$\mathbf{r}$} & \multirow[t]{2}{*}{ Nilai $\mathrm{p}$} \\
\hline & \multicolumn{2}{|c|}{ Baik } & \multicolumn{3}{|c|}{ Kurang Baik } & & & \\
\hline & f & $\%$ & f & $\%$ & f & $\%$ & \multirow{4}{*}{0,217} & \multirow{4}{*}{0,045} \\
\hline Tinggi & 46 & 75,4 & 15 & 24,6 & 61 & 100 & & \\
\hline Rendah & 0 & 0 & 1 & 100 & 1 & 100 & & \\
\hline Total & 46 & 74,2 & 16 & 25,8 & 62 & 100 & & \\
\hline
\end{tabular}

Tabel 4 mendeskripsikan nilai $r$ dari kelompok dukungan sebaya dan kualitas hidup adalah 0,217 dan nilai nilai $p$ adalah $0,045(\mathrm{p}<0,05)$. Berdasarkan hasil analisis

\section{PEMBAHASAN}

\section{A. Karakteristik ODHA di KDS Arjuna Plus Semarang.}

(Widiyanti et al., 2019) mengatakan rentang usia 17-35 tahun termasuk dalam kategori usiareproduktif . Kelompok usia reproduktif dipengaruhi oleh kebutuhan dan dorongan seksual meningkat sehingga melakukan berbagai cara dalam memenuhi kebutuhan. Keadaan tersebut beresiko terhadap penularan penyakit infeksi menular seksual salah satunya HIV/AIDS. Kelompok usia reproduktif berpersepsi bahwa memiliki status kesehatan yang baik sehingga secara psikologis mengabaikan perilaku beresiko terhadap munculnya penyakit atau masalah kesehatan (Widiyanti et al., 2019). Sesuai dengan penelitian (Hasanah, 2017) menunjukkan bahwa mayoritas ODHA pada kelompok usia 20 sampai 35 tahun yaitu sebanyak 34 ODHA. data dapat disimpulkan bahwa kelompok dukungan sebaya berhubungan dengan kualitas hidup pada ODHA di KDS Arjuna Plus Semarang secara signifikan.

Penelitian (Kambu, 2012) juga menunjukkan mayoritas ODHA berusia 20-35 tahun. Sama halnya dengan laporan (Kementrian Kesehatan RI, 2014), persentase kumulatif kasus HIV/AIDS tertinggi di Indonesia pada kelompok usia 20 sampai 29 tahun. Penelitian (Saktina \& Satriyasa 2017) mendapatkan hasil bahwa kelompok usia ODHA terbanyak terdapat pada kelompok usia produktif yaitu 20 sampai 49 tahun. Seseorang individu dapat didiagnosis HIV/AIDS dapat berlangsung lama antara 5 sampai 12 tahun sejak terinfeksi HIV (N. Noviana, 2016). Klien yang terdiagnosis HIV/AIDS pada usia 30 sampai 40 tahun sudah terinfeksi virus HIV sejak usia remaja. Hal ini dapat disimpulkan bahwa usia produktif dapat berpengaruh terhadap aktifitas seksual yang berkaitan erat dengan penularan HIV/AIDS.

Berdasarkan jenis kelamin, perempuan memiliki kualitas hidup lebih rendah dibandingkan laki-laki. Sementara itu, 
terdapat perbedaan kebiasaan dalam hal menjaga kesehatan lingkungan antara lakilaki dan perempuan, sebagian besar perempuan lebih perhatian terhadap kesehatannya dibandingkan dengan lakilaki (Handayani \& Mardhiati, 2018). Penelitian (Butarbutar, 2015) menjelaskan mayoritas ODHA adalah laki-laki yaitu sebanyak 105 orang $(72,4 \%)$. Presentase ODHA pada laki-laki lebih banyak dibandingkan dengan perempuan yaitu sebesar $73 \%$ berbanding $27 \%$. Kasus pada laki-laki lebih tinggi karena perilaku seksual dan penyalahgunaan Narkoba, Psikotropika, dan Zat Adiktif (NAPZA) (Kementerian Kesehatan RI, 2011).

Hasil penelitian (Saktina \& Satriyasa 2017) menyebutkan proporsi ODHA didominasi oleh laki-laki dengan jumlah 121 klien (67,6\%). Proporsi ini diakibatkan karena mayoritas laki-laki melakukan hubungan seksual beresiko dan penggunaan NAPZA. Menurut (Infodatin Kemenkes RI, 2014), mayoritas ODHA adalah kelompok berjenis kelamin lakilaki pada tahun 2008-2014. Hasil penelitian dari (Nyoko et al., 2016) juga menunjukkan bahwa sebagian besar ODHA merupakan laki-laki yaitu 73 orang $(64,9 \%)$. Berdasarkan hal tersebut, jumlah laki-laki yang terinfeksi penyakit HIV/AIDS lebih banyak dibandingkan perempuan. Namun, kasus ODHA pada perempuan harus tetap dijadikan perhatian yang serius. Perempuan beresiko tinggi tertular virus HIV/AIDS dan lebih menderita akibat penyakit. Penularan HIV pada perempuan juga dapat berlanjut pada resiko menularnya pada bayi jika mereka hamil.

Faktor latar belakang pendidikan menjadi salah satu faktor yang mempengaruhi kualitas hidup dikarenakan pendidikan merupakan faktor sosiodemografi yang berhubungan dengan kualitas hidup. Tingkat pendidikan dapat mempengaruhi individu dalam meningkatkan kualitas hidupnya. Tingkat pendidikan dapat mempengaruhi individu untuk memahami suatu informasi dengan mudah (Handayani \& Mardhiati, 2018). Penelitian (Nyoko et al., 2016) juga menunjukkan sebagian ODHA berpendidikan SMA yaitu sebanyak 54 orang $(48,6 \%)$.

Penelitian dari (Butarbutar, 2015) menjelaskan bahwa proporsi ODHA berdasarkan dengan tingkat pendidikan yang tertinggi adalah SMA sebanyak 39 orang $(55,2 \%)$. Penyakit HIV/AIDS terjadi di semua tingkatan pendidikan. Faktanya meskipun seseorang memiliki pendidikan tinggi dan pengetahuan yang benar tentang HIV/AIDS, tidak menjamin untuk melakukan upayan pencegahan HIV/AIDS (Hasanah, 2017) menyatakan bahwa sebagian besar ODHA memiliki pendidikan tingkat SMA sebanyak 41 orang (78,8\%). Tingkat pendidikan berkaitan dengan kemampuan individu dalam menyerap dan menerima informasi kesehatan, selain itu juga pendidikan dapat berpengaruh terhadap perilaku seseorang yang lebih baik. Seseorang yang memiliki tingkat pendidikan tinggi akan mempunyai wawasan yang luas (Hasanah, 2017). Berdasarkan hal tersebut tingkat pendidikan berpengaruh terhadap kejadian HIV/AIDS jika dilihat dari aspek kesadaran dirinya sendiri.

Pekerjaan merupakan suatu hal penting di dalam kehidupan manusia, pekerjaan mengandung fungsi-fungsi psikologis. Statu pekerjaan berperan sebagai penguat identitas individu yang yang dapat 
meningkatkan kepercayaan diri individu tersebut. Penelitian lain (Saktina \& Satriyasa 2017) juga menyebutkan bahwa mayoritas ODHA bekerja sebagai pegawai swasta sebanyak 77 orang (43\%). Penelitian (Butarbutar, 2015) menunjukkan bahwa proporsi ODHA berdasarkan pekerjaan yang terbanyak adalah pegawai swasta yaitu 77 orang (53,1\%), serupa dengan Penelitian dari (Hasanah, 2017) menunjukkan distribusi ODHA sebanyak 38 orang $(73,1 \%)$ adalah pekerja swasta.

Seorang pekerja swasta yang memiliki penghasilan merasa mempunyai hak untuk mendapatkan sesuatu yang diinginkan dengan upah yang didapatkan, dalam hal ini meliputi hak untuk memuaskan nafsu (Hutapea, 2014). Peningkatan jumlah kasus HIV/AIDS jika dihubungkan dengan status pekerjaan dapat disimpulkan bahwa individu yang memiliki penghasilan sendiri cenderung melakukan apapun sesuai dengan keinginan. Termasuk salah satunya adalah perilaku seksual beresiko yang rentan terhadap penularan infeksi HIV/AIDS.

\section{B. Gambaran Kelompok Dukungan Sebaya dan Kualitas Hidup ODHA di KDS Arjuna Plus Semarang}

Mayoritas ODHA $(74,2 \%)$ di KDS Arjuna Plus Semarang memiliki kualitas hidup baik dan hampir seluruh $(98,4 \%)$ ODHA di KDS Arjuna Plus Semarang memiliki kelompok dukungan sebaya. Kualitas hidup merupakan suatu yang sangat penting dalam kesejahteraan hidup. Kualitas hidup merupakan suatu kondisi dimana ODHA tetap merasa baik meskipun ada penyakit yang dialaminya. Kualitas hidup yang baik jika didukung dengan lingkungan, kesehatan mental, kesehatan fisik, dan psikologis, dan hubungan sosial yang baik (Hardiansyah et al., 2014). Penelitian (Hardiansyah et al., 2014) menjelaskan bahwa setengahnya ODHA di Makassar memiliki kualitas hidup baik yaitu sebanyak 10 orang $(47,6 \%)$. Namun terdapat perbedaan pada penelitian lain (Prathama Limalvin et al., 2020) yang menyatakan bahwa mayoritas ODHA memiliki kualitas hidup rendah. ODHA mempersepsikan bahwa permasalahan yang dihadapi tidak hanya sebatas permasalahan fisik melainkan juga masalah psikologis, masalah ekonomi, dan spiritual. Masalah-masalah tersebut menurunkan kualitas hidup ODHA.

Menurut penelitian Huda(2018) menyatakan bahwa gambaran kualitas hidup ODHA di Yayasan Sahabat Mitra Sehat semakin memburuk. Kualitas hidup ODHA yang kurang baik dipengaruhi oleh masalah-masalah yang dihadapi seperti stigma dan diskriminasi masyarakat. Sehingga ODHA menunjukkan kepanikan, kecemasan, dan keputusasaan yang membuat psikologis ODHA terganggu. Berdasarkan hal tersebut upaya untuk meningkatkan kualitas hidup ODHA diperlukan guna meningkatkan kualitas hidup ODHA.

Penelitian (Irawan \& Purnamasari, 2017) juga menjelaskan bahwa ODHA yang memiliki kualitas hidup kurang baik lebih mendominasi yaitu sebanyak 22 orang dibandingkan dengan ODHA dengan kualitas hidup baik yaitu sebanyak 20 orang. Kualitas hidup ODHA yang kurang baik dipengaruhi oleh masalah psikologis akibat stigma dan diskriminasi yang membuat ODHA merasa terkucilkan dan tidak memiliki semangat untuk hidup. 
Salah satu bentuk intervensi yang dapat meningkatkan motivasi hidup sehingga kualitas hidup meningkat yaitu adanya dukungan dari kelompok sebaya.

Penelitian (Handayani \& Mardhiati, 2018) menunjukkan bahwa hampir seluruh ODHA memiliki Kelompok Dukungan Sebaya (KDS) yang tinggi yaitu sebesar 61 orang $(98,4 \%)$. KDS merupakan sebuah kelompok terdiri dari dua atau lebih individu berkumpul menjadi satu untuk memberikan dukungan yang bertujuan mencapai kualitas hidup lebih baik. Penelitian dari (Johan et al., 2014) menjelaskan KDS berperan meningkatkan kualitas hidup ODHA sehingga berpengaruh positif terhadap pembentukan kepercayaan diri, pengetahuan tentang HIV/AIDS, perilaku dan pencegahan penularan HIV/AIDS, dan melakukan kegiatan-kegiatan yang positif. KDS membantu ODHA untuk mengurangi stigma-stigma dan diskriminasi di dalam masyarakat. Keuntungan dari KDS adalah dapat meningkatkan kualitas hidup ODHA, meningkatkan dukungan sosial, melalui kegiatan berbagi pengalaman antar ODHA (Johan et al., 2014).

KDS merupakan sebuah kelompok yang bertujuan untuk memberikan dukungan bagi setiap anggota kelompok dalam kehidupan sehari-hari. KDS membantu meningkatkan kepercayaan diri, pemahaman tentang penyakit HIV/AIDS, akses pelayanan HIV/AIDS, perilaku pencegahan penularan penyakit HIV/AIDS, dan kegiatan-kegiatan positif yang lebih baik dibandingkan dengan ODHA yang tidak memiliki dukungan sebaya. KDS memberikan manfaat positif untuk mendorong perilaku seks yang aman dan memiliki kepercayaan yang lebih tinggi untuk menghindari kekerasan seksual. KDS memiliki peran yang yang sangat baik dalam menjalani perawatan dan pengobatan, memotivasi dan memberikan dukungan mental dan spiritual kepada ODHA untuk berjuang melawan penyakitnya (Anok, Aniroh \& Wahyuni, 2018).

\section{Kelompok Dukungan Sebaya (KDS) berhubungan dengan Kualitas Hidup ODHA di KDS Arjuna Plus Semarang}

Hasil penelitian menunjukkan terdapat hubungan signfiikan antara dukungan kelompok sebaya dan kualitas hidup pada ODHA di KDS Arjuna Plus Semarang. HIV/AIDS trmasuk dalam penyakit kronis yang harus dihadapi dengan sikap dan perilaku yang positif. Semakin positif sikap dan perilaku ODHA terhadap manajemen diri penyakit HIV/AIDS, maka semakin baik ODHA dalam mengikuti pengobatan penyakit HIV/ AIDS sehingga virus HIV dapat terkontrol. Menurut (Ikbal and Safitri, 2017) HIV/AIDS menyebabkan kualitas hidup ODHA memburuk. Beberapa faktornya adalah penyakit HIV merupakan penyakit kronis, efek samping konsumsi obat Anti Retroviral (ARV) sepanjang hidup. Dalam kehidupan sehari hari ODHA dihadapkan dengan permasalahan yang cukup kumpleks. Permasalahannya tidak hanya dari sisi fisiologis akibat terinfeksi HIV dan keteraturan pengobatan ARV tetapi juga dihadapkan dengan adanya stigma dari masyarakat yang membuat beban psikologis yang dapat mempengaruhi kualitas hidup ODHA. Stigma masyarakat terhadap ODHA menjadi hambatan terbesar dalam upaya pencegahan, perawatan, proses pengobatan, dan 
dukungan terhadap ODHA (Diatmi \& Fridari, 2014).

Hardiansyah et al. (2014) mengatakan kualitas hidup adalah sesuatu yang penting pada aspek kesejahteraan hidup bagi ODHA. Dimana kondisi ini ODHA tetap merasa baik meskipun ada penyakit yang dialami. (Handayani \& Mardhiati, 2018) menjelaskan bahwa kualitas hidup menjadi tujuan utama dalam pemberian asuhan dan dukungan. Kualitas hidup berdasarkan WHO terdiri dari aspek fisik, aspek mental, aspek sosial, aspek spiritual, dan aspek lingkungan. Berbagai cara dapat ditempuh untuk meningkatkan kualitas hidup ODHA, namun Kelompok Dukungan Sebaya (KDS) dirasa lebih efektif dibandingkan dengan intervensi lain. KDS memberikan pelajaran bagaimana cara hidup bermasyarakat dan mempengaruhi penanganan masalah sosial ODHA. ODHA mampu mengenal kehidupan yang demokratis dalam KDS, sehingga memiliki kesempatan melakukan berbagai macam kegiatan dalam kelompok sosial.

KDS merupakakan sebuah kelompok dimana didalamnya terdapat beberapa individu yang terinfeksi penyakit HIV bergabung menjadi satu yang memberikan dukungan dengan tujuan untuk mencapai kualitas hidup yang lebih baik (Handayani and Mardhiati, 2018). KDS membantu ODHA untuk meminimalisir stigma masyarakat melalui pemberian informasi kepada pihak-pihak yang melakukan diskriminasi tersebut. Keuntungan dari KDS dapat meningkatkan dukungan sosial, mengurangi stigma, sebagai wadah untuk berbagi pengalaman serta meningkatkan kualitas hidup ODHA (Johan et al., 2014). Penelitian (Ikbal and Safitri, 2017) mengatakan bahwa kelompok dukungan sebaya berhubungan dengan kualitas hidup ODHA di Yayasan Lantera Minangkabau Support Padang tahun 2016 nilai $\mathrm{p}=0,000$ $(\mathrm{p}<0,05)$.

Penelitian (Mufarika, 2019) berpendapat bahwa terdapat hubungan antara kelompok dukungan sebaya dan kualitas hidup ODHA nilai $\mathrm{p}=0,000 \quad(\mathrm{p}<0,05)$. Hal tersebut selaras dengan penelitian (Rasyiid, 2016) yang menggambarkan adanya hubungan positif antara peran KDS dan kualitas hidup pada ODHA. Penelitian (Rozi, 2016) menjelaskan bahwa terdapat hubungan kelompok dukungan sebaya terhadap kualitas hidup ODHA nilai $\mathrm{p}=$ $0,018(\mathrm{p}<0,05)$. Nilai koefisiensi korelasi 0,305 menunjukkan kelompok dukungan sebaya dengan kualitas hidup memiliki hubungan positif, yaitu semakin baik KDS maka semakin tinggi kualitas hidup ODHA. HIV/AIDS merupakan penyakit seumur hidup sehingga membuat kualitas hidup ODHA menurun. Tidak hanya permasalahan fisiologis saja, ODHA juga dihadapkan dengan stigma masyarakat yang menyebabkan ODHA tidak percaya diri dan tidak memiliki harapan untuk hidup, sehingga kualitas hidup ODHA tidak stabil. KDS memiliki peran dalam meningkatkan kepercayaan diri dan kualitas hidup melalui kegiatan-kegiatan yang positif.

\section{KESIMPULAN}

Kelompok dukungan sebaya dan kualitas hidup ODHA di KDS Arjuna Plus Semarang memiliki hubungan yang signifikan. Hasil penelitian dapat digunakan sebagai data dasar dalam mengembangkan penelitian dengan melibatkan variabel lain seperti hubungan 
KDS terhadap kepatuhan pengobatan. Perawat sebagai pemberi perawatan, konselor, pendidik, manajer kasus dapat mengoptimalkan peran KDS dalam proses layanan kesehatan terhadap ODHA melalui kegiatan-kegiatan yang positif sehingga kualitas hidup ODHA semakin meningkat. Keperawatan sebagai ilmu dapat mengembangkan intervensi berbasis kelompok yang dapat meningkatkan status kesehatan dan kualitas hidup individu dengan penyakit kronis seperti HIV/AIDS.

\section{DAFTAR PUSTAKA}

Ade Tedi Irawan; Tiara Purnamasari. (2017). Faktor-Faktor Yang Berhubungan Dengan Kualitas Hidup Pasien Penderita Hiv/Aids Di Poli Klinik Akasia Rsud Majalengka Tahun 2016. Syntax Literate, 2(Jurnal Ilmiah Indonesia), Vol 2 No 4 (2017): Syntax Literate. http://jurnal.syntaxliterate.co.id/index.ph $\mathrm{p} /$ syntax-literate/article/view/94.

Anok, Maria Regolinda; Umi Aniroh, S. W. (2018). Hubungan Peran Kelompok Dukungan Sebaya dengan Kepatuhan ODHA dalam Mengkonsumsi ARV di Klinik VCT RSUD Ambarawa. Jurnal Ilmu Keperawatan Maternitas, 1(2), 814.

Butarbutar, J. T. (2015). Karakteristik Penderita HIV/AIDS di RSUD Dr. Djasamen Saragih Pematangsiantar Tahun 2013 - 2014. Universitas Sumatera Utara.

Diatmi, K., \& Fridari, I. G. A. D. (2014). Hubungan Antara Dukungan Sosial dengan Kualitas Hidup pada Orang Dengan HIV dan AIDS (ODHA) Di Yayasan Spirit Paramacitta. Jurnal Psikologi Udayana, 1(2), 353-362. https://doi.org/10.24843/jpu.2014.v01.i0 2.p14.

Dinas Kesehatan Kota Semarang. (2018). Profil Kesehatan Kota Semarang 2015.
In Dinkes.Semarang.Go.Id. http://www.depkes.go.id/resources/downl oad/profil/PROFIL_KAB_KOTA_2015/ 3374_Jateng_Kota_Semarang_2015.pdf.

Dinkes Provinsi Jawa Tengah. (2015). Profil Kesehatan Provinsi Jawa Tengah 2015. Dinkes Provinsi Jawa Tengah.

Handayani, S., \& Mardhiati, R. (2018). Keberlanjutan Peran Dukungan Sebaya di Dalam Sistem Penanggulangan HIV di Tingkat Provinsi dan Kota/Kabupaten Indonesia. Perilaku Dan Promosi Kesehatan: Indonesian Journal of Health Promotion and Behavior, 1(1), 44. https://doi.org/10.47034/ppk.v1i1.2093.

Hardiansyah, Amiruddin, R., \& Arsyad, D. S. (2014). Kualitas Hidup Orang Dengan HIV dan AIDS di Kota Makassar. Media Kesehatan Masyarakat Indonesia, 1-11.

Hasanah, R. A. (2017). Gambaran Karakteristik pada Pasien Penyakit HIV/AIDS di Puskesmas Gedingtengen Kota Yogyakarta Tahun 2015. In STIKes Jenderal Achmad Yani Yogyakarta. STIKes Jenderal Achmad Yani Yogyakarta.

Huda, D. M. (2018). Bimbingan Kualitas Hidup terhadap Orang dengan HIV/AIDS (ODHA) dI Yayasan Sahabat Sehat Mitra Sebaya (YASEMA) Sukoharjo. INSTITUT AGAMA ISLAM NEGERI SURAKARTA.

Hutapea, R. (2014). AIDS \& PMS dan Pemerkosaan. Rineka Cipta.

Ikbal, R. N., \& Safitri, S. A. (2017). ODHA Di Yayasan Lantera Minangkabau Support Padang Tahun 2016. Jurnal Ilmu Kesehatan, 1(1), 87-91.

Infodatin Kemenkes RI. (2014). Infodatin AIDS.pdf. In Situasi dan Analisis HIV AIDS (pp. 1-8). http://www.depkes.go.id/resources/downl oad/pusdatin/infodatin/Infodatin AIDS.pdf.

Johan, T., Wahyuni, T. D., \& Pitoyo, J. (2014). Hubungan Peran KDS (Kelompok 
Dukungan Sebaya) dengan Kepatuhan Minum Obat pada ODHA. Poltekkes Kemenkes Malang.

Kambu, Y. (2012). Analisis Faktor-Faktor yang Mempengaruhi Tindakan Pencegahan Penularan HIV oleh ODHA di Sorong.

Kemenkes RI. (2018). Situasi Umum HIV/AIDS dan Tes HIV. Kementerian Kesehatan Republik Indonesia.

Kementerian Kesehatan RI. (2011). Pusat Data dan Informasi Profil Kesehatan Indonesia 2010. In Direktorat Jendral Kesehatan Ibu dan Anak. Kementerian Kesehatan Republik Indonesia. http://www.depkes.go.id.

Kementrian Kesehatan RI. (2014). Profil Kesehatan Indonesia Tahun 2013. In Kemenkes RI. Kementerian Kesehatan Republik Indonesia. https://doi.org/10.1088/03054470/14/8/037.

Maharani, F. (2017). Faktor -Faktor Yang Berhubungan Dengan Stigma Terhadap Orang Dengan Hiv Dan Aids (Odha). Jurnal Endurance, 2(2), 158. https://doi.org/10.22216/jen.v2i2.1300.

Mufarika, M. (2019). Kualitas Hidup, Dukungan Sebaya, Hubungan Peran Kelompok Dukungan Sebaya dengan Kualitas Hidup Orang HIV/AIDS (ODHA) di Poli VCT RSUD Syarifah Ambami Rato Ebu Bangkalan. Jurnal Keperawatan Malang, 3(2), 67-74. https://doi.org/10.36916/jkm.v3i2.68

N. Noviana. (2016). Konsep HIV-AIDS
Seksualitas dan Kesehatan Reproduksi. CV Trans Media.

Nyoko, Y. O., Hara, M. K., \& Abselian, U. P. (2016). Karakteristik Penderita HIV/AIDS di Sumba Timur tahun 20102016. Jurnal Kesehatan Primer, 1(1), 415.

Prathama Limalvin, N., Wulan Sucipta Putri, W. C., \& Kartika Sari, K. A. (2020). Gambaran dampak psikologis, sosial dan ekonomi pada ODHA di Yayasan Spirit Paramacitta Denpasar. Intisari Sains Medis, $\quad 11(1), \quad 81$. https://doi.org/10.15562/ism.v11i1.208.

Rasyiid, A. (2016). The Effect of Peer Support Group on Depression and Quality of Life among People Living with HIV/AIDS in Kediri East Java. Journal of Health Promotion and Behavior, 01(01), 32-40. https://doi.org/10.26911/thejhpb.2016.01. 01.05

Rozi, R. F. (2016). Hubungan Dukungan Sosial dengan Kualitas Hidup ODHA pada Kelompok Dukungan Sebaya Solo Plus di Surakarta. Keperawatan, Kualitas Hidup, 1-14.

Saktina, P., \& Satriyasa, B. (2017). Karakteristik Penderita Aids Dan Infeksi Oportunistik Di Rumah Sakit Umum Pusat Sanglah Denpasar Periode Juli 2013 Sampai Juni 2014. E-Jurnal Medika Udayana, 6(3), 1-6.

Widiyanti, M., Hadi, M. I., Adiningsih, S., Alamudi, M. Y., \& Kumalasari, M. L. F. (2019). Karakteristik Demografi ODHA di Papua. Journal of Health Science and Prevention, 3(1), 10-15. https://doi.org/10.29080/jhsp.v3i1.175 